\title{
FOOD SECURITY IN SOUTH ASIA AND SELF-RELIANCE IN PADDY
}

\author{
M. Aryal ${ }^{1}$ and M. Kandel ${ }^{2}$
}

\begin{abstract}
South Asia is world most densely populated region and houses the largest population of undernourished people. It remains the world's second poorest region with more than 500 million people living on less than US\$1.25 per day. Firstly this paper attempts to show the general situation and production trend of paddy, secondly, scrutinizes the role paddy has been playing in the economy and food security so far and that it is still the most potential means to improve the food security situation and tackle severe under-nutrition as other sectors are, until now, far less furnished to address this issue. This paper probes into various economic and historical perspectives of rice economy and culture in this region, and shows that self-sufficiency in paddy production is paramount to its domestic food security, and thereby proposes that emphasis should be given on increased rice production which is decelerating amid expansion of modern economic sectors.
\end{abstract}

Keywords: Food security, Paddy, Self-sufficiency, South Asia, Gross Domestic Product

\section{INTRODUCTION}

South Asian houses well over $1 / 5^{\text {th }}$ of the world's population and nearly $1 / 5^{\text {th }}$ of world's undernourished people. Despite unprecedented economic progresses in past three decades, millions of people remain food-insecure. The Green Revolution has immensely influenced various aspects of food security in India, tripling its food grain production between 1960 and 2000 (Estudillo et al., 2010) and thus halving the percentages of food insecurity and poverty. In Asia, food security has traditionally been defined as maintaining stable prices for rice in the major urban markets of a country (Asia foundation, 2010) where it is the staple food of more than $50 \%$ of the population. For South Asia the figure is around 70\% (FAOSTAT) which is highest in the world, and hence food security is essentially a reflection of rice security in this region. And thus achieving self-reliance in rice production is an effective way to promote national level food security. Indeed, this analysis considers the many supporting facts. Firstly, the countries in this region share significant similarities in terms of livelihood, diet, culture, lifestyle and socio-economic status and are characterized by widespread poverty, under-nutrition and low literacy rate. Thus, it assumes implementation of a somewhat identical measure to face an issue as local and as global as food insecurity. Secondly, it is a developing region and the economy is chiefly agrarian. No other sector of the economy is likely to bring a sustainable level of food security for the fast growing population as effectively as the rice industry is doing at present. Last but not least, natural disasters, political instability, malgovernance and transnational crime are widespread in South Asia and continue to cripple development issues and opportunities. No significant interventions are possible in such cases to ameliorate the condition of food security, irrespective of production status.

Nepal is a land locked and least developed country, having a population of more than 28 million people with the annual growth rate of $1.35 \%$. It is estimated that the country's population in 2025 will reach 40.5 million, with anticipated difficulties of fulfilling the food requirements (FAO, 2006). It is frequently exposed to varieties of human made and natural disasters. It is also likely to face

1 Senior Agri. Economist, Ministry of Agricultural Development, Singh Darbar, Kathmandu Corresponding : maniaryal7@gmail.com

2 School of Environmental Science and Management, New Baneswor, Kathmandu 
strong effects of climate change. Economic growth was primarily in non-agricultural sectors, which target $7.2 \%$ while for agricultural growth $4.7 \%$ per annum in the coming $14^{\text {th }}$ three year plan (NPC, 2016). Apart from the small holding, other sources of income are livestock, wages, remittance, etc. Nearly $50 \%$ of the small and marginal farmers and majority of the landless agricultural workers live below the poverty line. Chronic poverty and deep-rooted social divisions and discrimination in terms of caste, ethnicity, gender, culture and religion creates much vulnerability to poverty, food insecurity and malnutrition. Country poverty is root cause for food insecurity, under-nutrition, social and education and employment deprivations. Low productivity in agriculture is a major contributor to poverty and food insecurity. Country's poverty is decreased by $21.6 \%$ during $2013 / 14-2015 / 16$, with wide variations in areas, gender, caste and ethnicity (NPC, 2016). Poverty is worst in the remote hills and mountains of Far and Mid-Western Nepal, about 60\% of the population lives below nation poverty line and local production is generally sufficient for only three to six months (CBS, WFP and WB, 2006). Price of food commodities are hiking and income of miserable people is stagnant, rather decreasing. Due to insufficient food production and limitation of agricultural income, farmers are compelled to do other activities for livelihoods. However, due to low wage and seasonal engagement, incomes from those activities are not sufficient to maintain the needs as well as food secure.

\section{MATERIAL AND METHODS}

This paper is mainly based on review of secondary sources. This paper focuses on five South Asian countries namely India, Nepal, Bangladesh, Sri Lanka and Pakistan and main data sources are from their ministries of agriculture. Other sources include the World Bank, FAOSTAT, IRRI, International Food Policy Research Institute (IFPRI), Bangladesh Rice Research Institute (BRRI), Consultative Group on International Agricultural Research (CGIAR), United States Department of Agriculture (USDA) and CBS, Nepal and research papers. India and Bangladesh rank among top five global producers and the two largest producers and consumers of rice in South Asia, and also because their rice consumption plays a vital role in the rice economy of South Asia and the whole world. The agricultural growth is weak in Nepal compared to other countries in South Asia, and in recent years, the rate has slowed (MoAC, WFP and FAO, 2009). According to a detail report on agriculture policy and strategies for poverty alleviation and food security, agriculture poor performance reflects two closely related problems (FAO and UNDP, 2003). First, little arable land that is not presently farmed, so any expansion of cultivated area is either at the expense of forests, or onto low potential marginal lands, in addition to severe soil erosion, the result is shrinking average farm size and increasing fragmentation, leading to growing poverty and food insecurity.

\section{FINDINGS AND DISCUSSIONS}

\section{Paddy profile}

In paddy production, South Asia has made a quantum jump since the spread of the green revolution in 1960 s. With $41 \%$ arable land, it is currently the second largest rice producing region in the world (Gumma et al., 2011). Paddy is a staple for the majority of the 1.7 billion South Asian population and a source of livelihood for more than 50 million households. Apart from its economic and strategic importance, rice is deeply engraved in the rich tradition and culture of many South Asian countries. In India and Nepal, rice offerings to bring good health and prosperity to family members are common on many auspicious occasions. The significance of rice extends beyond life for Hindu communities in the region with offerings given to the departed soul. One can find many religious and cultural uses of rice throughout South Asia. The region cultivates rice on 60 million hectares and 
produces slightly above 225 million tons, accounting for $37.5 \%$ of the global area and $32 \%$ of global production in 2013. Within South Asia, both India and Bangladesh are major rice-growing countries. The Pakistan, Nepal and Sri Lanka-together have slightly above 5.6 million hectares and produce 19.5 million tons in 2016. The majority of this production increase in the past five decades has come from yield growth, with harvested area growing by only $20 \%$ from 50 million hectares in the late 1960s to 60 million hectares now (IRRI, 2016).

India and Bangladesh has become the world's second and fourth largest rice producing nation with the largest rice harvesting area (USDA, 2016). According to data from the last 40 years, the per capita rice consumption rate in Bangladesh is $171.73 \mathrm{Kg}$ per person per year. In Pakistan, wheat is the staple food yet. Paddy production in Sri Lanka for 2015/2016 recorded high of 4.5 million tons. South Asia imported 0.66 million tons of rice in 2016, with Nepal the largest buyer. Only India and Pakistan are self-sufficient in rice production; Sri Lanka, Bangladesh and Nepal are not yet selfsufficient and depend on imports from other countries (Figures 1 and 2 ).

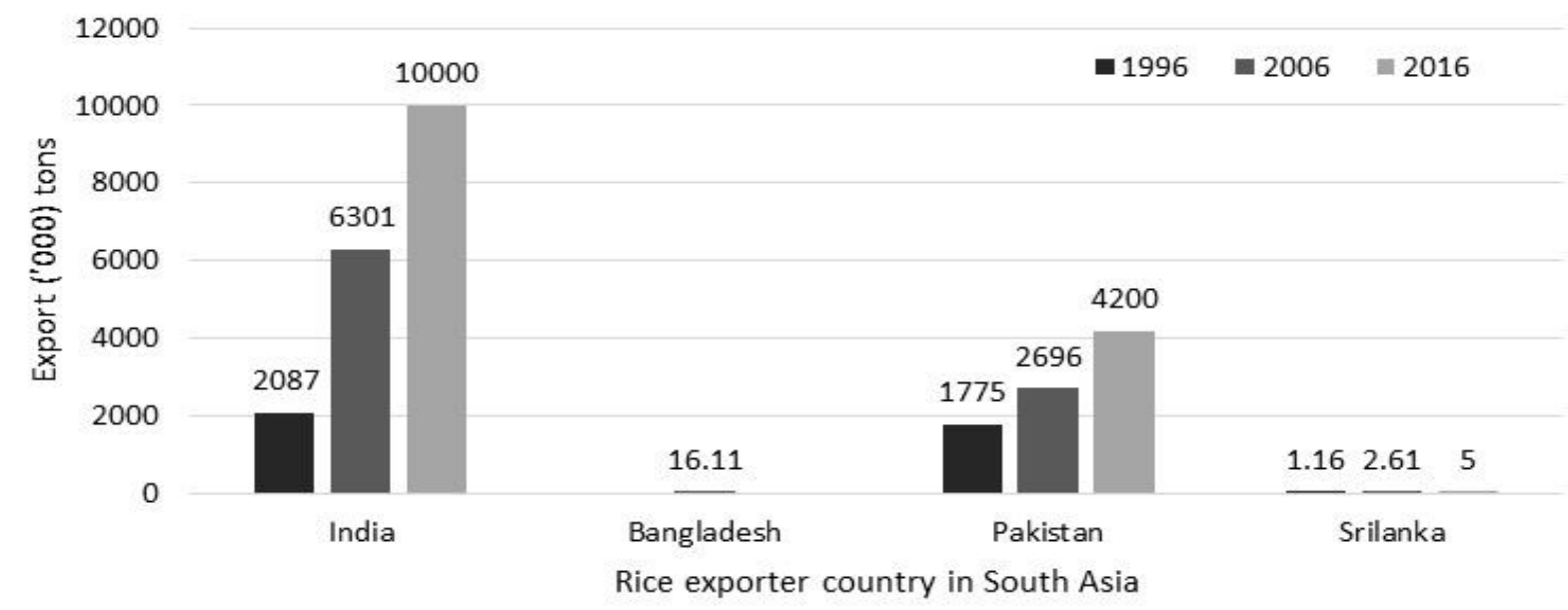

Figure 1: Rice exports in thousand tons by year

Source: USDA, 2016

Figure 1 Shows that India is the major exporter of rice from South Asia selling about 100 million tons in 2016. Pakistan is the only other exporting country but the volume is much lower compared to India.

Figure 2: Rice imports in thousand tons by year

(Source: USDA, 2016)

Figure 2 Shows the trend of rice import by Nepal, Bangladesh and Sri Lanka. Nepal is highly dependent on import from others countries and the biggest importer of rice in South Asia. India is the only one self-sufficient country in the region in 2016.

Rice occupies about $46.5 \%$ of total cropped area and contributes $54 \%$ of total cereal production in Nepal in 2016. During the mid 1990's Nepal had national food deficit of $14.3 \%$ however this varied greatly by region with $79 \%$ in the mountains and $36 \%$ in the Hills, with the Terai region being the only area to produce a surplus, 7\% (Gill, et al, 2003). The 1995-97 periods saw a dramatic increase in food insecurity and deprivation up to $26 \%$ of the population, with a wide geographic distribution, potentially related to political turmoil (FAO, 2003). An estimate by MoAD indicates a food grain shortage of 1,32,910 Mt for 2008/09 but in 2012/13, there was a food surplus of 4,08,442 Mt (MoAD, 2014/15). Dalit were worst affected and most critical months for food insecurity are March, April, 
July, August and September (50\% food insecurity in July- September) due to severe flood, road obstruction, rise in food prices, and decreased production. In general, food security situation will be achieved in November-December due to harvesting season of the paddy. Agriculture production is generally poor in the hills and mountain region of Nepal, particularly food deficit and more vulnerable to drought. The low production is largely due to the predominance of rainfed agriculture, traditional farming practices, limited agri-input, inadequate technical advice for farmers due to poor extension services, poverty and limited availability of credit, and frequent droughts and floods.

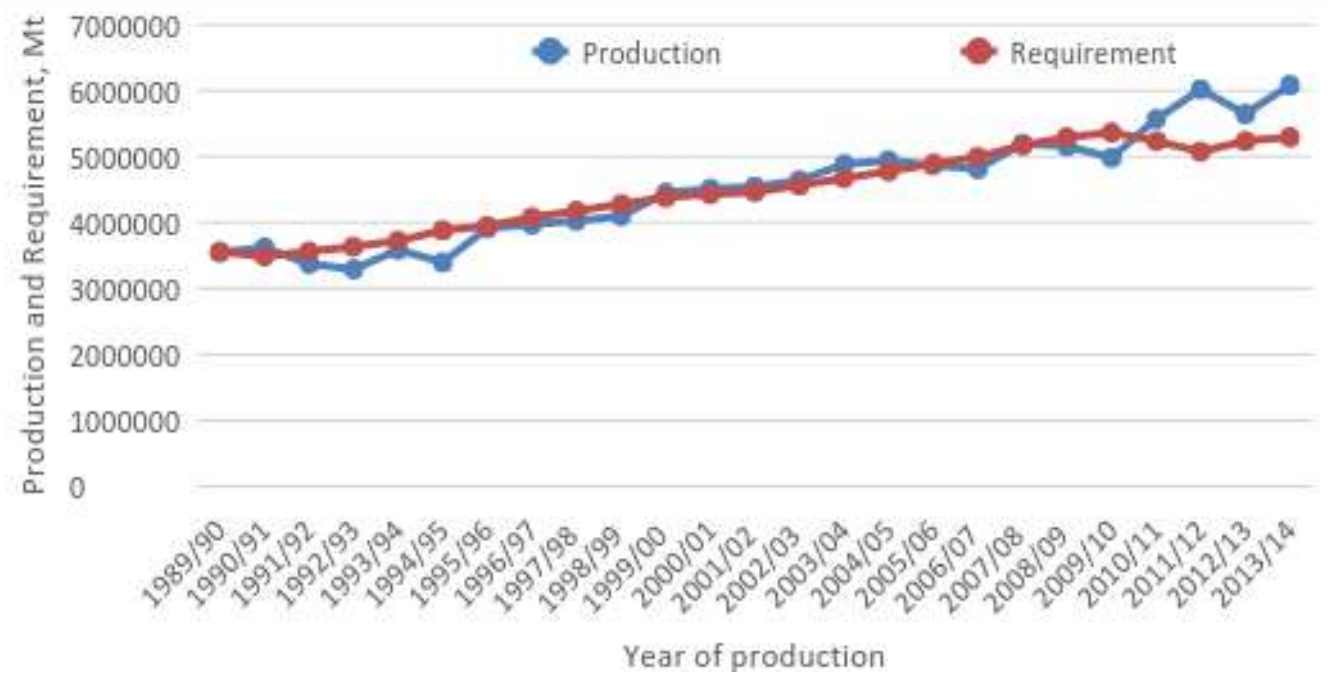

Figure 3: Food availability and requirement of Nepal

(Source : MoAD, 2014/15)

Figure 3 shows the trend of food availability for consumption and requirement from 1989/90 to 2013/14. During this period, 2005/06, 2006/07, 2008/09 and 2009/10 were the year of food deficit and other periods are the year of food surplus.

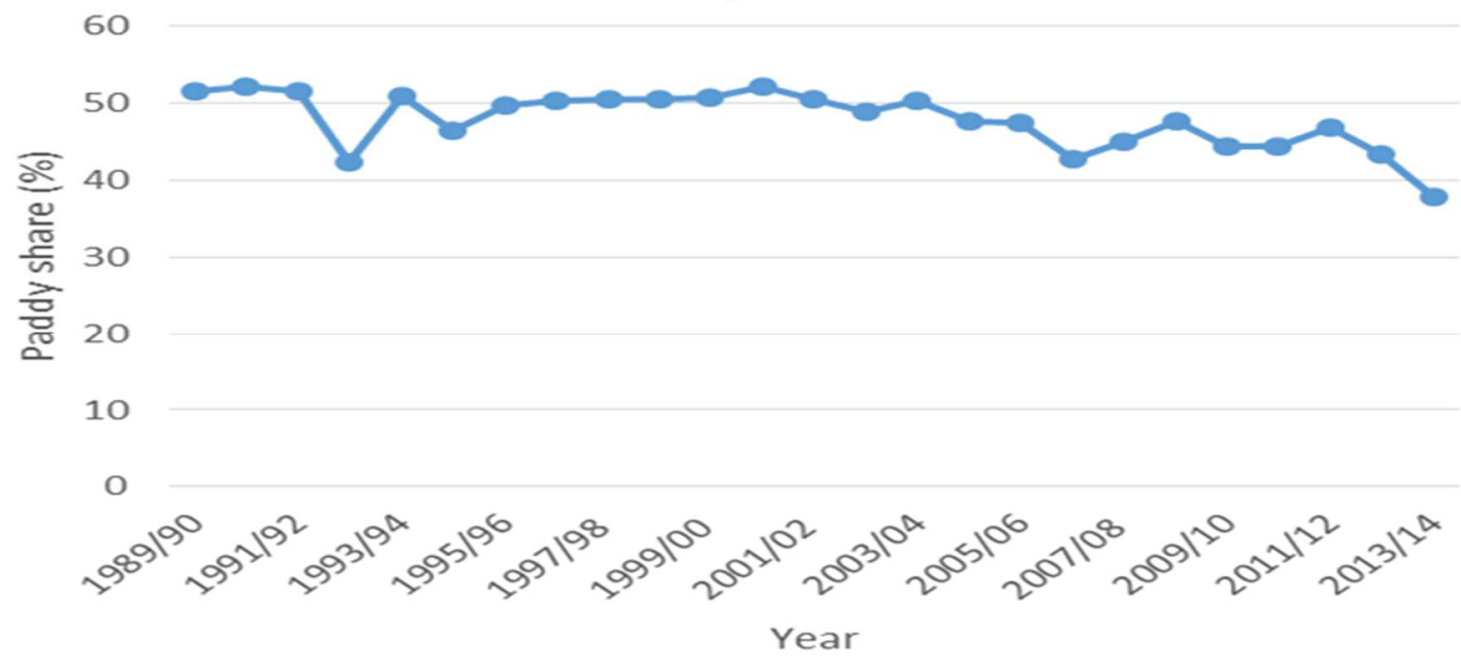

Figure 4: Paddy share among total production for consumption Source: MoAD, 2014/15 
The figure 4 showed that paddy share was above $50 \%$ before 2000 and found declining and reached below $40 \%$ in $2013 / 14$ in total production among cereal crops. Contribution of rice in food security was found decreasing in recent years. The reason behind this may be the unavailability of rice in hill and mountain, lack of transportation facility to transport from terai to mountain, increased in price per $\mathrm{Kg}$ and increased population and also the consumption pattern of the consumer.

\section{Share of Paddy in agriculture and Gross Domestic Product (GDP)}

Agriculture has historically been a dominant sector in South Asian economy, employing about $60 \%$ of the labor force and contributing $22 \%$ of the regional GDP. In Nepal, agriculture remains the principal economic activity, employing $60.5 \%$ of the population and providing $32.6 \%$ of GDP (Economic survey, 2015/16. Sri Lanka's rice sector contributes 30\% to the agricultural GDP (Mendis, 2009). Rice is the single most important crop occupying $34 \%$ ( 0.77 million hectares) of the total cultivated area in Sri Lanka. In 2003, India and Bangladesh together contributed 28\% (22 and 6 respectively) of global rice production and $33.57 \%$ in 2009 (26 and 7.5 respectively). However, the share of rice in total agricultural output (Figure 5) and total GDP has been declining. In 1961, rice accounted for $8.4 \%$ of GDP in South Asia, declined to $2.7 \%$ in 2007.

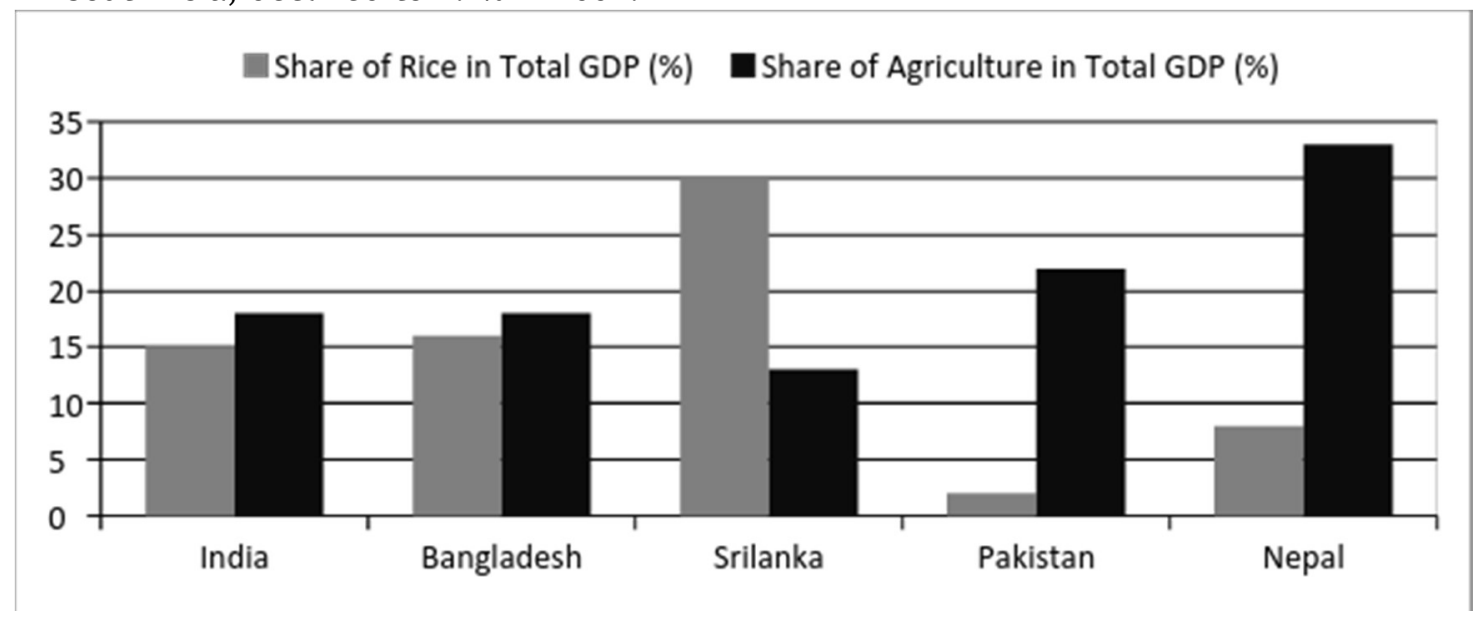

Figure 5: Share of rice and agriculture in total GDP, 2010-11

Figure 5 shows the percentage share of agriculture and rice in total GDP in 2010/2011. Pakistan's agricultural share in total GDP is higher than that of India and Bangladesh but contribution of rice to total GDP remains much lower. Rice contributes the lions share in GDP for Sri Lanka, while India and Bangladesh show a similar pattern of dependency on rice. For Nepal, agriculture has the biggest share in total GDP comparing to the other four countries but shows that contribution of rice to GDP is comparatively higher.

\section{Importance of rice and consumption pattern in South Asia}

Rice is the cheapest and most effective means available in this region that is likely to eradicate acute under-nutrition. Many studies have revealed that there is a great potential to increase the rice production and productivity in South Asia. India, Bangladesh and Sri Lanka are among the most disaster-prone countries in the world. Recurrent floods, cyclones, earthquakes, landslides and droughts hugely affect the production in these countries. Still they have maintained a steady growth for the last three decades (Figure 7). And now with the advent of modern breeding strategies, which has proved to be much more efficient than conventional techniques, and environmental stress- 
tolerant varieties, the whole scenario for rice production appears better than ever. The Indian subcontinent has a tradition which is inseparably mingled with rice, is more than mere livelihood and has shaped the history, culture, art, and lifestyle of its population in many ways. It is regarded as a sign of fortune and well-being in many South Asian societies. In weddings, seasonal festivals, and rituals, rice plays an inevitable part. The amount of rice consumed in this region explains how important rice is in their lives (Table 1). The so-called Rice-Lentil soul and curry is an iconic menu seen across the entire Indian subcontinent. Bhat (cooked rice) is the term for meal in many South Asian languages. In Hindu rituals, paddy is an indispensable item. Two panicles of paddy appear on many logos, monograms and bank notes in Bangladesh.

Table 1: Per capita consumption pattern in South Asia

\begin{tabular}{l|cccc}
\hline \multirow{2}{*}{ Country } & \multicolumn{4}{|c}{ Per capita Consumption(Kg/person/year) } \\
\cline { 2 - 5 } & $1970-1972$ & $1989-1991$ & $1999-2001$ & $\mathbf{2 0 1 1 - 2 0 1 3}$ \\
\hline Bangladesh & 150 & 153 & 155 & 171.73 \\
India & 69 & 79 & 76 & 69.49 \\
Nepal & 82 & 106 & 99 & 87.75 \\
Pakistan & 29 & 14 & 13 & 12.25 \\
Sri lanka & 95 & 93 & 94 & 109.72 \\
\hline
\end{tabular}

Source: adapted from FAOSTAT database.

Table 1 shows that in terms of per capita consumption, Bangladesh is the largest consumer of rice which explains why it depends on imports every year despite having the highest production rate. Sri Lanka holds the second position in per capita consumption of rice. Nepal and India show a similar rice-consumption pattern. Pakistan is the country least dependent on rice.

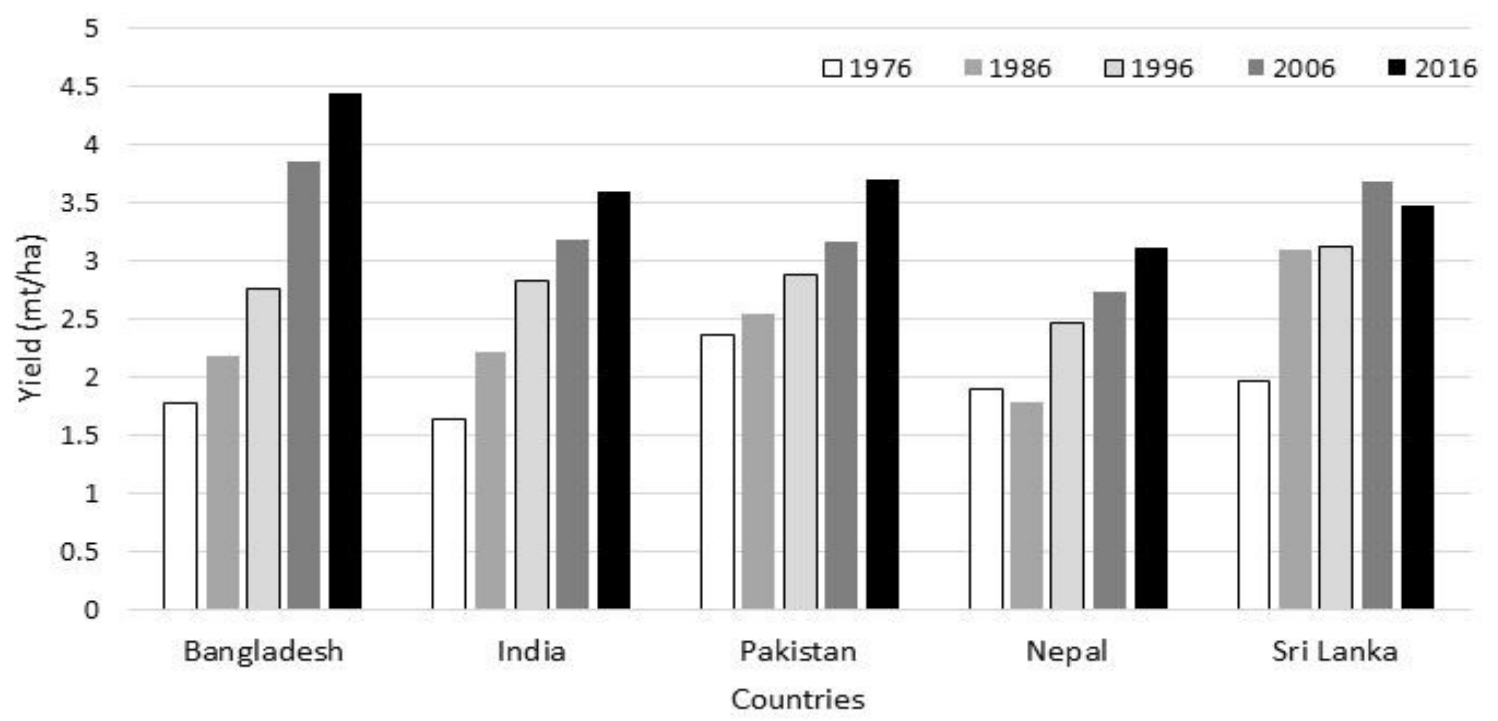

Source: United States Department of Agriculture

Figure 7: Paddy yield (Mt/ha) 
Figure 7 Shows that Bangladesh, Pakistan and Sri Lanka has been the highest rice yielding nations since 1976 in South Asia. All the countries except Nepal have shown an increasing yield since 1976. The lowest rice yield was found in Nepal compared to other south Asian countries.

\section{Future prospects and importance of rice research in South Asia}

The population in South Asia is predicted to exceed six billion by the end of the century and may face a severe food shortage unless production can keep pace with the increased demand. Also, there are many crucial problems including water scarcity, decreasing size of agricultural land, inadequacy of agrochemicals, power shortage and poor infrastructure. Yet there is a ray of hope shed on the future of rice by biotechnology which ensures greater productivity. Additionally, sub continental soil is suitable for rice and production per unit of land is considerable. However, the demand for food is only rising and is being met by constantly diminishing resources. To boost production, increasing amounts of fertilizer and pesticides are being used and aggravating environmental and ecological problems. Thus the need for a sustainable intervention to these urgencies necessitates innovation in rice technology and development of varieties which are not only high yielding but also can be produced in more eco-friendly ways. The development of high yielding varieties(HYVs) and bio-fortified, disease-, insect-, flood-, drought-, saline-, herbicide- and stress-resistant rice has opened anew era in the history of rice and will boost rice production in near future. Genetic engineering has offered rice cultivars resistant to herbicide, salinity and drought. Malnutrition, being a widespread problem in this region, requires an immediate intervention which may be very effectively addressed by bio-fortified rice. Rice bio-fortified with iron and zinc can protect against certain deficiency diseases and people who have no access to commercially marketed fortified foods and supplements will greatly benefit from it. Golden rice, which is a genetically modified strain of rice and enriched with beta-carotene, has the potential to save millions of children from blindness and other deadly consequences of acute vitamin A deficiency. More and more biotechnologists around the world are working to develop such micronutrient-rich rice varieties which were not possible by conventional breeding technologies. Field trials are also being undertaken to estimate any potential health impacts of the newly innovated rice cultivars. Gene banks have a major role to play in preserving the native cultivars and the artificially designed ones. From a food security perspective, gene banks are invaluable as they provide all the past cultivar options and if a variety fails to due to certain causes, farmers still can turn to gene banks for the varieties that were previously available. Food security has four pillar like, availability, access, utilization and sustainable. South Asian countries had focused on availability section. Remaining three pillars had also played great role to achieve food security. Remittance and introduction of Nepal Food Cooperation (NFC) has changed the food habits in Nepal. People living in remote districts depend on rice for food due to availability of food through NFC and remittance has increased the purchasing capacity of people. Therefore, the country has to focus on food habits of the people and promote the local foods for consumption. Not only self sufficiency in rice but also changing in food habits may play crucial role to achieve food security in near future.

\section{Regional rice economy}

Food security is a multifaceted issue influenced by national and international policy making; social, economic, environmental and demographic variables being the most prominent ones. Rice is not only the staple crop of South Asia, it is also a political crop. Large rice stocks are maintained by many countries and remain untraded until market prices rise abnormally high, and consequently food scarcity remains a common scenario across many poor areas. Though South Asian Association for Regional Cooperation (SAARC) countries has launched the South Asia Food Security Program, there is still a lot to be done. Lack of mutual cooperation has long debilitated the region's 
socioeconomic development. Shockingly, in terms of regional trade, South Asia is the world's least integrated territory, trade between the countries accounting for less than two percent of the gross domestic production (GDP) of the region. Promoting regional cooperation and integration with neighboring organizations like Association of Southeast Asian Nations (ASEAN) can prove to be phenomenal in alleviating poverty and achieving food security. Cross-border trading, mutual work on scientific and technological research, and improved communication will greatly facilitate the region's political, economic, and social welfare and would enable the countries to mitigate against food crisis and other related issues more effectively. It is therefore of utmost importance to strengthen regional cooperation and build ties across political borders to increase trade and improve regional food security.

6. Rice production and Nepalese context

Table 2: Production trend of cereal crops in Nepal and Rice contribution ('000 Mt)

\begin{tabular}{|c|c|c|c|c|c|c|}
\hline \multirow{2}{*}{ Cereal Crops } & $1964 / 65$ & $1984 / 85$ & $1994 / 95$ & $2012 / 13$ & $2013 / 14$ & \multirow{2}{*}{$\begin{array}{c}\text { 2013/14 } \\
\text { Percentage }\end{array}$} \\
\hline & 3270 & 4210 & 5440 & 8817.6 & 9562.3 & \\
\hline Paddy & 2201 & 2709 & 2906 & 4504 & 5047 & 52.78 \\
\hline Maize & 854 & 820 & 1302 & 2078 & 2283 & 23.88 \\
\hline Wheat & 126 & 534 & 942 & 1882 & 1883 & 19.69 \\
\hline Barley & 26 & 23 & 37 & 37 & 35 & 0.37 \\
\hline Millet & 63 & 124 & 253 & 306 & 304 & 3.18 \\
\hline Buckwheat & & & & 10.6 & 10.3 & 0.11 \\
\hline
\end{tabular}

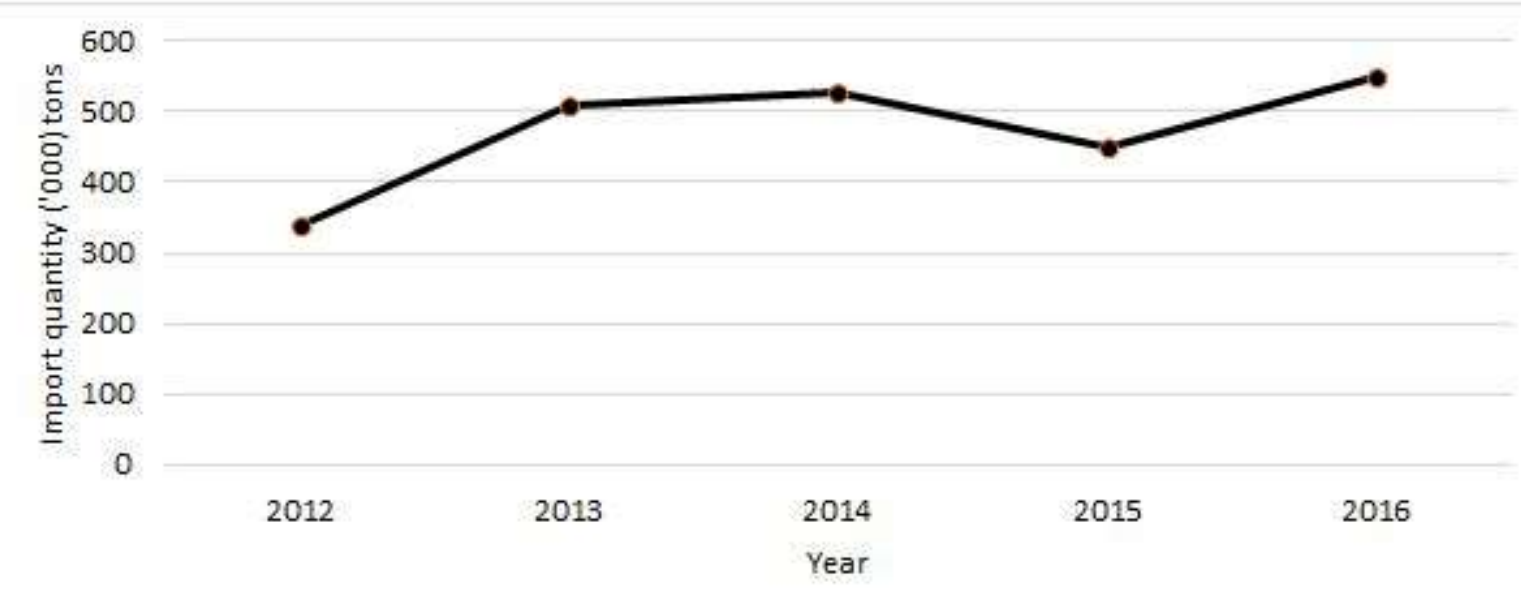

Figure 8: $\quad$ Import of rice by Nepal in differtn years Source : USDA, 2016

From table 2, among cereal crops, rice contributes more than $50 \%$ of the total production as well as edible grain production. Rice is the major crop for food security of any households. Majority of the 
people consumed rice two times per day. Food balance sheet in Nepal includes edible portion of the major cereals-rice, maize, wheat, millet and barley (MOAD, 2014). Availability of the edible portion of the food grain from domestic production shows that rice contributes nearly a half $(48 \%)$ to the total edible food grain production. Another half of the food grain is contributed by maize and wheat. Mostly people consumed rice everyday. Therefore, rice production determines the food security of the individual or family. If agricultural production in Nepal is adversely affected by the climate change, the livelihoods of two-thirds of the labor force, particularly of the rural poor will be at threat. Food sufficiency at the national level during good crop harvest, however, not necessarily mean food security at the household and individual levels in the country due to unavailability, poor access, poor utilization and vulnerability at different parts of the country. Figure 8 shows the import quantity of rice was increasing by Nepal since 2012 and reached to 550,000 tons in 2015 .

\section{CONCLUSION}

It is apprehensible that sustained production of rice is central to food security. Sub-continental land is quite capable of being self-sufficient in rice production and India and Pakistan have already proved that. Since poverty is another direct cause of food insecurity, people can move out of stark poverty if they can be employed in agricultural activities and many such projects are already in operation in many countries. From the present South Asian perspective, there is no other easier way to promote national food security than through gaining self-sufficiency in rice production. Raising agricultural production is evidently the most direct way to tackle food insecurity in agronomic countries and agronomy is essentially rice economy in South Asia. The fact that most of the poor and undernourished people of South Asia are living in rural areas, and that they are largely dependent on agriculture for their livelihood can be a problem and a solution at the same time. Since agriculture is the mainstay of its economy, and the ratio of rice land to arable land is high in the subcontinent, there remains an opportunity to expand domestic rice production by creating employment and income generating opportunities in the face of ever increasing demand for rice. If self-sufficiency is achieved, it will create scope for surplus production. Also, having a surplus of rice will allow rural people to profit and can lift them above the poverty line. In a strict sense, income generation and food security initiatives go hand-in-hand and this reality makes rice more important to food security in South Asia. This paper thus substantiates that agriculture is the backbone to the South Asian economy and that rice, being the staple agricultural product, holds the capacity to pull people out of stark poverty and ensure sustainable availability of food for the food-insecure population. Food required in Nepal is largely met by domestic production and food inadequacy during bad production years is about five percent of the total consumption. The bad production comes mainly from widespread droughts and sometimes from localized floods. Food sufficiency at the national level during good crop harvest, however, not necessarily mean food security at the household and individual levels in the country due to unavailability, poor access, poor utilization and vulnerability at different parts of the country and for many households.

\section{REFERENCES}

Asia Foundation, 2010. Food security in Asia and the changing role of rice.Asia foundation, Australia; 2010.

Alam, M.S., Alam, M.R., \& Islam, K.K., 2005. Energy flow in agriculture: Bangladesh. American Journal of Environment Science. 1:3. ISSN: 1553-345X.

Bishwajit, G., Sarker, S., Kpoghomou, M., Gao, H., Jun, Liu.,Yim, D., \& Ghosh, S., 2013. Self-sufficiency in rice and food security: a South Asian perspective. Agriculture \& Food Security 2013, 2:10.

CBS, WFP and WB, 2006.Small Area Estimation of Poverty, Caloric Intake and Malnutrition in Nepal. 
DAC, 2012.Agricultural Census Division. India: Ministry of Agriculture; Department of Agriculture and Cooperation. http://pib.nic.in/archieve/others/2012/mar/d2012031302.pdf.

Estudillo, J.P. and Keijiro, O., 2010. Rural poverty and income dynamics in Southeast Asia. Handbook of Agriculture Economics. 4:3435. http://www.sciencedirect.com/science/article/pii/S1574007209040675.

FAO/WFP CFSAM, 2008. Handbook of Agricultural Statistics: Bangladesh Ministry of agriculture. Retrieved from http: //www.moa.gov.bd/statistics/statistics.htm on 20th Nov, 2013.

FAO, 2006. Nepal Food Security and Nutrition Monitoring/Early System Assessment of Current System, Project Design and Proposal. FAO, Rome.

FAO, 2003. Trade Reforms and Food Security: Conceptualising the linkage, Commodity Policy and Projection Service, Commodities and Trade Division, FAO, Rome.

GoB, 2011.Bangladesh economic review. Finance Division, Ministry of Finance Economic Adviser's Wing, Bangladesh Government Press.

Gumma, M.K., Nelson, A., Thenkabail, P.S. \& Singh, A.N., 2011.Mapping rice areas of South Asia using MODIS multi-temporal data. Journal of Applied Remote Sens 5:3.

IRRI, 2012. Top 10 rice consuming countries. International Rice Research Institute, Philipines. Retrieved from http://www.irri.org on 15th August 2015.

Kevin, D. W., 2011. Gallagher National Agricultural Research Centre (NARC). Pakistan: FAO Representation; 2011. http://www.fao.org/fileadmin/templates/rap/files/epublications/PakistanedocFINAL.pdf.

Kumar, M., 2008. Nepal economic growth assessment.Agriculture, 2008.

Mendis, A., 2009. Sri Lanka GRAIN annual, global agricultural information network, GAIN report number: CE9002. Sri Lanka: USDA foreign agricultural service.

MoAC, WFP \& FAO, 2009. Crop and Food Security Assessment: 2014/15 Winter Drought in Nepal, Joint Assessment Report - May 2015. Kathmandu

MoAD, 2015.Statistical information on Nepalese Agriculture, 2015/16.Ministry of Agriculture Development, Kathmandu, Nepal.

MoAD, 2014.Statistical information on Nepalese Agriculture, 2014/15.Ministry of Agriculture Development, Kathmandu, Nepal.

Mohammad, d. C., 2009. Sustainability of accelerated rice production in Bangladesh: technological issues and the environment. Bangladesh Journal of Agriculture, 2009, 34(3):523.

NPC, 2016.Three year Interim plan 2012/13-2014/15. National Planning Commission. Kathmandu.

SDNP, 2002.Agricultural database. Sustainable Development Networking Program (SDNP); Dhaka, Bangladesh. Downloaded from http://www.sdnbd.org/sdi/issues/agriculture/index.htm on 10th September 2012.

UNDP, 2009. Human Development Report 2009 Overcoming Barriers: Human Ability and Development. Oxford University Press, New York.

USDA, 2012.Agriculture database. United States: Department of Agriculture. Downloaded from http://www.indexmundi.com/agriculture on 25th September 2012.

USDA, 2012. Rice situation and outlook yearbook, Market and trade economics division, economic research service. U.S: Department of Agriculture: RCS-2012.

USDA, 2012.Rice statistics. USA: United States department of agriculture (USDA). http://www.indexmundi.com/agriculture/.

WH, 2008. Revival of agriculture; south Asia agriculture.World Hunger and Poverty Facts and Statistics. World hunger.http://www.worldhunger.org/articles/Learn/world\%20hunger\%20facts\%202002. htm\#Number_of_hungry_people_in_the_world.

WFP and MoAC, 2009. District level food Security Monitoring: Resource material MoAC, Government of Nepal and world Food Programme, Kathmandu.

WFP, 2016. Nepal Food Security Bulletin, Issue -41. WFP, Kathmandu.

ICRISAT, 2008. WWF-ICRISAT: SRI fact sheet. INDIA; 2008.http://www.sri-india.net/documents/india.pdf. 